\section{Other medication options}

Ibuprofen has been shown to be at least as effective as paracetamol ${ }^{13,14}$ but is more likely to produce gastrointestinal and renal adverse effects. One suspects that if ibuprofen is used as widely as paracetamol then inevitably its toxicity and adverse effects will become a problem.

Further population studies are required to establish the safety and pitfalls of a regimen using a limited number of doses of paracetamol and/or ibuprofen.

While aspirin is also effective, its widespread use cannot be recommended because of its gastrointestinal and platelet effects, and an association with the rare Reye's syndrome.

\section{Summary}

- Paracetamol has a mild symptomatic benefit in childhood febrile illness

- Paracetamol toxicity data are increasingly worrying

- The various strengths of paracetamol mixtures are a major health hazard

- Paracetamol has not yet been shown to prevent febrile convulsions

\section{Recommendations}

1. There should be a concerted medical and pharmaceutical campaign to warn of the indiscriminate use of antipyretics in mild viral febrile illness in childhood.

2. An initial paracetamol dose of $15 \mathrm{mg} / \mathrm{kg}$ could be given, followed by three doses of $15 \mathrm{mg} / \mathrm{kg}$ over the next 24 hours if irritability continues.

3. No more than these four doses of paracetamol to be given for any one illness unless under medical or pharmacist supervision.

4. Each bottle of paracetamol mixture should have the $\mathrm{mg} / \mathrm{mL}$ concentration in huge letters on the label, with the words 'Beware, potentially toxic' on the $100 \mathrm{mg} / \mathrm{mL}$ bottle. Consideration should be given to withdrawal of all but the lowest strength.

5. Treat the child, not the thermometer.
REFERENCES

1. Shann F. Paracetamol: when, why and how much [editorial]. J Paediatr Child Health 1993;29:84-5.

2. Graham NM, Burrell CJ, Douglas RM, Debelle P, Davies L. Adverse effects of aspirin, acetaminophen, and ibuprofen on immune function, viral shedding, and clinical status in rhinovirus-infected volunteers. J Infect Dis 1990;162:1277-82.

3. Schmitt BD. Fever phobia: misconceptions of parents about fevers. Am J Dis Child 1980;134:176-81.

4. Fagan E, Wannan G. Reducing paracetamol overdoses [editorial]. $\mathrm{Br}$ Med J 1996;313:1417-8.

5. Miles FK, Kamath R, Dorney SF, Gaskin KJ, O'Loughlin EV. Accidental paracetamol overdosing and fulminant hepatic failure in children. Med J Aust 1999;171:472-5.

6. Heubi JE, Barbacci MB, Zimmerman HJ. Therapeutic misadventures with acetaminophen: Hepatotoxicity after multiple doses in children. J Pediatr 1998;132:22-7.

7. Kramer MS, Naimark LE, Roberts-Brauer R, McDougall A, Leduc DG. Risks and benefits of paracetamol antipyresis in young children with fever of presumed viral origin. Lancet 1991;337:591-4.

8. Tarkka R, Rantala H, Uhari M, Pokka T. Risk of recurrence and outcome after the first febrile seizure. Pediatr Neurol 1998;18:218-20.

9. Schnaiderman D, LahatE, Sheefer T, Aladjem M. Antipyretic effectiveness of acetaminophen in febrile seizures: ongoing prophylaxis versus sporadic usage. Eur J Pediatr 1993;152:747-9.

10. Berg AT, Shinnar S, Shapiro ED, Salomon ME, Crain EF, Hauser WA. Risk factors for a first febrile seizure: a matched case-control study. Epilepsia 1995;36:334-41.

11. Uhari M, Rantala H, Vainionpaa L, Kurttila R. Effect of acetaminophen and of low intermittent doses of diazepam on prevention of recurrences of febrile seizures. J Pediatr 1995;126:991-5.

12. Aksoylar S, Aksit S, Caglayan S, Yaprak I, Bakiler R, Cetin F. Evaluation of sponging and antipyretic medication to reduce body temperature in febrile children. Acta Paediatr Jpn 1997;39:215-7.

13. McIntyre J, Hull D. Comparing efficacy and tolerability of ibuprofen and paracetamol in fever. Arch Dis Child 1996;74:164-7.

14. Walson PD, Galletta G, Chomilo F, Braden NJ, Sawyer LA, Scheinbaum ML. Comparison of multidose ibuprofen and acetaminophen therapy in febrile children. Am J Dis Child 1992;146:626-32.

\section{Self-test questions}

The following statements are either true or false (answers on page 67)

5. Viral shedding times are reduced by paracetamol.

6. Antipyretic prophylaxis is effective at preventing febrile seizures.

\title{
Paracetamol: overused in childhood fever
}

\section{- a consumer perspective}

\section{Dell Horey, Maternity Alliance; and Helen Hopkins, Consumers' Health Forum}

Dr Hewson's paper recommends a concerted medical and pharmaceutical campaign to warn against the indiscriminate use of medicines such as paracetamol to treat mild viral fevers in children. Perhaps a more appropriate focus for the campaign would be the safe and appropriate use of paracetamol in childhood illnesses, including information about other measures parents can use to help their child feel more comfortable while recovering.

Parents need the information in recommendations 2 to 4 of the paper. They need to know what dose of paracetamol to give, 
how frequently this dose can be safely given and how long they should continue treatment before consulting a health professional again. It is also extremely important that parents and other carers, including grandparents and other family members who might help to supervise a sick child, know the importance of checking the strength of the paracetamol mixtures and the correct dose. People need to be aware that too much paracetamol may be toxic. Stressing how important it is to store the medicine safely where children cannot reach it would reinforce the message about the possibility of harmful overdose.

Changing family and social patterns may mean parents are turning to their general practitioner or pharmacist for practical advice and reassurance that previously came from family or friends. As well as reminding parents about the appropriate use of paracetamol and the dangers of overdose, doctors may need to provide practical advice about other care measures. It is important that doctors check that parents understand what is really meant by directions such as 'keep up the fluids', 'sponge if they are getting too hot' and 'plenty of rest'. Parents want the best for their children, but they may need guidance about what that comprises.

\section{Recognising serious illness in babies}

Useful information for parents on how to recognise serious illness in babies has been prepared by Professor Peter Hewson. It can be found in the internet version of Australian Prescriber Vol 23 No 3.

\section{Treating head lice}

\section{Orli Wargon, Dermatologist, Sydney}

\section{SYNOPSIS}

Head lice (Pediculosis capitis) is a common condition in children. It is usually detected in schools, when children are seen scratching their heads. The diagnosis can be confirmed by finding live adult lice or viable eggs. Lice are usually adequately treated with an over-the-counter topical permethrin preparation. Treatment failure results from inadequate therapy, re-infection, resistance to the insecticide or an underlying immunosuppression. Prescription drugs such as ivermectin may be needed in more difficult cases.

Index words: Pediculosis capitis, permethrin, maldison, ivermectin.

(Aust Prescr 2000;23:62-3)

\section{Background}

Blood sucking lice of the order Anoplura are successful obligate ectoparasites of humans. ${ }^{1}$ Pediculus humanus capitis, the head louse, is a distinct clinical form. It clings to hair with its claws and feeds by sucking blood from the scalp. Its life cycle is about 17-20 days with eggs hatching 7-10 days after they are laid, and adults are fully developed about 10 days later. ${ }^{2}$ Head lice spread by head to head contact.

\section{Diagnosis}

A child found to be scratching their head at school is often checked by the teacher, school nurse or public health personnel. If they are well trained or experienced they will look for live adult lice on the crown of the scalp, immature nymphs or viable eggs. Empty shells or nits adhere to the hair, $1 \mathrm{~cm}$ from the scalp surface, with a glue-like substance. They are unlike seborrhoeic scales, hair casts and hair spray, which are easily brushed off.

\section{Treatment}

Three types of insecticide are marketed worldwide. In my local pharmacies all insecticide products for head lice are either permethrins $10 \mathrm{mg} / \mathrm{mL}$ as shampoos, lotions or creme rinses or maldison products with $0.5 \%$ alcohol bases, $1 \%$ foam bases, shampoos or soaking solutions.

Alcoholic lotions have greater ovicidal activity ${ }^{3}$, the creme rinses are less ovicidal than liquids and lotions ${ }^{4}$ and shampoo formulations have low ovicidal activity and may not kill eggs. ${ }^{5}$ In theory, one application should kill all lice and eggs. However, in vitro studies $^{3,4}$ suggest that some eggs can survive and require a second application after seven days. Surviving eggs can cause reinfestation if not removed.

Everyone who has been in contact with the patient should be examined and treated if affected. It is also advisable to wash all clothes, head gear, towels, bed linen, combs and brushes as head lice can survive away from the human host for about three days and eggs can survive for up to 10 days.

Permethrin (3 phenoxybenzyl cis trans3(2,2-dichlorvinyl)2,2 dimethyl cyclopropane carboxylate) is a synthetic pyrethroid. It acts on parasitic nerve cell membranes and has low mammalian toxicity, but incomplete ovicidal properties. ${ }^{6}$ Patients apply permethrin to the hair for 10 minutes then wash 